\title{
MEASURING VIBRATION AT TRACTOR PLATFORM , STEERING WHEEL AND SEAT EFFECTIVE AMPLITUDE TRANSMISSIBILITY FACTOR DURING OPERATION TILLAGE
}

\author{
A. A. H. Al-Mafrachi \\ Lecturer \\ Email: ahmed.abd23@yahoo.com \\ University of Baghdad - Dormitories Affair Department
}

\begin{abstract}
Field experiment conducted to measure vibrations on three axes longitudinal $X$, lateral $Y$ and vertical $Z$ on steering wheel, platform tractor and vertical vibration in seat tractor and seat effective amplitude transmissibility (SEAT) factor during operation tillage in silt clay loam soil with depth $18 \mathrm{~cm}$ in Baghdad. Split split plot design under randomized complete block design with three replications least significant design $5 \%$ used. Three factor were used in this experiment included two types of plows included chisel and disc plows which represented main plot, three tires inflation pressure was second factor included $1.1,1.8$ and 2.7 bar, and three forward speeds of the tillage was third factor included $2.35,4.25$ and $6.50 \mathrm{~km} / \mathrm{hr}$. Results showed disc plow recorded higher vibration values for three axes $X, Y$ and $Z$ on platform, steering wheel and vertical vibration seat tractor. No significant effect between chisel and disc plows in (SEAT) Factor. Tier pressure 2.7 bar recorded higher vibration values in all measurements. Speed tractor $6.50 \mathrm{~km} / \mathrm{hr}$ recorded higher vibration values in all measurements. Vibration values increasing when increasing tiers inflation pressure and tractor speed. All interaction among treatments significant. Level of vibration in these experiment a cross legislated permissible vibration exposure limits in the world except the vibration transmitted to steering wheel and tractor seat during tillage under 1.1 bar and tractor speed $2.35 \mathrm{~km} / \mathrm{hr}$.
\end{abstract}

Keywords: Soil, Tillage Speed, Disc and Chisel Plow, Tire Pressure, Vibration, Tractor Platform.

المفرجي مجلة العلوم الزراعية العراقية - 47(1): 365- 2016 /

قياس الاهتزازات لمنصة الجرار وعجلة القيادة ومعامل سعة المنقولية الفعالة للمقعد خلال عملية حراثة

$$
\text { أحمد عبد علي حامد المفرجي }
$$

Email : ahmed.abd23@yahoo.com

جامعة بغداد - قسم شؤون الأقتسام الاخلية

نفذت تجربة حقلية لقياس الاهتزازات بثلاثة اتجاهات الطولي X والجانبي y والعامودي z في عجلة القيادة ومنصة قيادة الجرار والاهتزاز العامودي

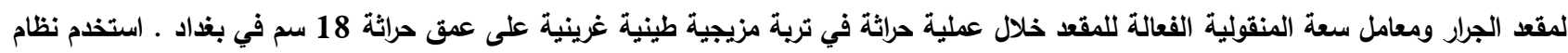

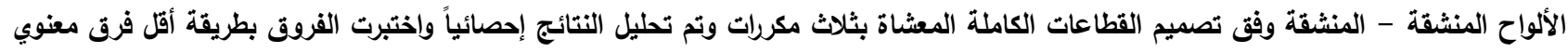

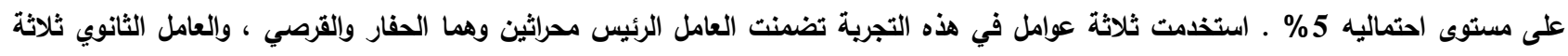
ضغوط للإطارات 1.1 و 1.8 و 2.7 بار ، والعامل تحت الثانوي ثلاثة سرع للجرار عثد الحراثة 2.35 و 4.54 و 2.50 و 6.50 كم/ ساعة ـ ـ أظهرت النتائج

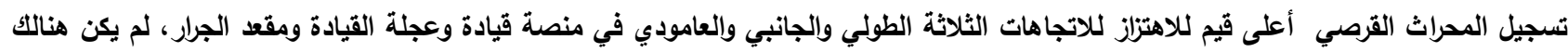
تأثير معنوي للمحراثين الحفار والقرصي في الصفة المدروسة معامل سعة المنقولية الفعالة للمقعد ـ ضغط الإطار 2.7 بار وسرعة الحراثة 6.50

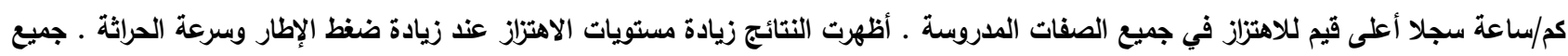

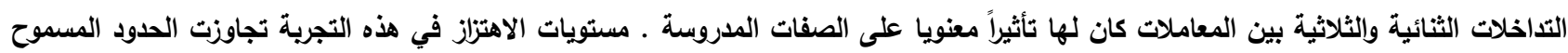

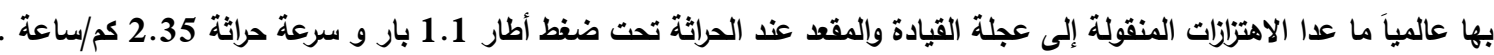

كلمات مفتاحية: الترية، سرعة الحراثة ، المحراث القرصي والحفار، ضغط الإطار، الاهتزازات، منصة قيادة الجرار. 


\section{INTRODUCTION}

Tractors have become the most important power source in the modern Iraq agriculture. In Iraq, unfortunately we have not a healthy organizations or unions care to the employees such as tractor drivers and workers safety like other develop countries (1). Modern tractors are often equipped without any type of suspension, and the tires, which are relatively flexible, are virtually only suspension that absorbs the vibrations, this is why the tractor drivers are subject to relatively high-level vibrations (2, 3 and 4). The nature of vibration present in a tractor depends upon the dynamic characteristics of the tractor and road surface characters. Vibration effect on the human body which depends mainly on the frequency, magnitude, direction of vibration, area of contact and duration of exposure (5). The quality of agricultural field operations such as soil tillage transmitted higher vibration levels to steering wheel tractor $(6,7$ and 8$)$. Excessive vibrations compromise quality, contribute to mechanical failures, and subject the operator to deafness and disorders of the spinal column and stomach. These excessive vibrations may be due to inadequate operating conditions of agricultural tractors such as irregular tire inflation pressure, incorrect ballast addition, extreme forward travel speed and others (9 and 10). Air pressure in tires was varied, over- inflated tires cause too much of the tractor weight to be supported by the air pressure present inside of them. In this case the tractor is bouncy and more difficult to control, the reason behind this is a small contact area of a tire when practically only a central part of a tires is in contact with the field surface, with increasing pressure the damping efficiency was observed to decrease. Another important factor that gives rise to vibration level is the speed of a tractor. Some measurements have shown that at the same tillage depth, vibration level along all three axes is increased by even $40 \%$ if the speed is increased by $3 \mathrm{~km} / \mathrm{h}$ only (11). Excessive soil tillage can contribute to high levels of incident vibration on the tractor, which is transmitted to the operator through the seat, platform and steering wheel. Hamid 2012 (1), Servadio et al. 2007(3) and Villibor 2014 (12) found in experiment conventional tillage ( disc plow) increasing level vibration when increasing forward tractor speeds and the vibration was higher according to ISO 2631-1:1997 (13). Multiplied vibration levels that occur in a complex system such as tractor are transmitted to the operator through the seat, the steering wheel, the supports and the floor of the cab as well as foot controls (14). The main sources of steering wheel vibration are engine imbalance, resonance of steering system, lesser damping, road, field operation induced vibration, etc.(15). Hamid et al 2011(7) found in a experiment that increasing level vibration transmitted to steering wheel in three dimension ( $\mathrm{x}, \mathrm{y}$ and $\mathrm{z}$ ) when increasing forward tractor speeds during conventional tillage. Surface type, driving speed and tires pressure tractor appeared to be the most important contributors to vibration exposure (16 and 17). Nguyen 2011(18) found that increasing level vibration when increasing speed and tire pressure. Vibration from tractor and machines passing through the seat into the driver's body through the buttocks, this is Whole Body Vibration (WBV). Whole body vibration can also pass from the platform of a tractor or machine to the operator through the feet. Hand-arm vibration means mechanical vibration which is transmitted from steering wheel to the hands and arms. Tire characteristics are depend on a lot of factors, for example tractor speeds, inflation pressure and tire temperature (19). According to Kising and GoKhlich 1989 (20) damping decreases substantially with increasing speed and decreases slightly with increasing inflation pressure. When tier pressure inflation was Increasing cause to increasing of tire stiffness . Deboli et al., 2008 (4) found when the tractor speed and tires pressure where increasing from 0.8 to 1.2 to $1.6 \mathrm{bar}$, it would be increasing of vibration levels. The aim of these experiment is to measure the vibration and the effects chisel, disc plows, the differents tires inflation pressure, the tractor varied speeding on the steering wheel, the platform tractor vibrations, seat effective amplitude transmissibility (SEAT) factor and to compare these levels vibration with legislated permissible vibration exposure limits in the world . 


\section{1-Material and Methods}

\section{1-1 Field Experiment}

The experiment was conducted in the field of Baghdad. The field was not cultivated and tilled for three years ago. Field was above $31.7 \mathrm{~m}$ from sea level, the weather temperature was measured at $33 \mathrm{C}^{\mathbf{o}}$, the humidity was 56 $\%$, soil texture was silt clay loam $(465,423$ and 112 g.kg-1). Tillage depth was $18 \mathrm{~cm}$ and soil moisture was $17-19 \%$ when soil tilled.

\section{2-1 Experimental Design}

Split-split plot design under randomized complete block design with three replication, least significant design (LSD) $5 \%$ used to compare the mean of treatments. Statistical analysis system used (12 and 22). The three factors in the experiment included two types of plows chisel and disc plows which represented the main plot, three pressures of tire inflation which second factor was included $1.1,1.8$ and 2.7 bar, three forward speeds of the tillage was third factor included $2.35,4.25$ and 6.50 $\mathrm{km} / \mathrm{hr}$. the Experiment contented 18 treatments with three replication for each treatment $(2 \times 3 \times 3 \times 3=54)$ Treatments .

\section{3-1 Tractor and Plows}

Chisel and disc plows as represented main plot, mounted behind TUMOSON 95-80 tractor and adjusted each of them on tillage depth $18 \mathrm{~cm}$. The main specifications of the tractor, tires, chisel and disc plows are listed in Tables 1,2 and 3. According to ISO 5008:2002 (23) recommended tractor must use without cap, tractor must work with full fuel tank and radiator, but without optional front and rear weights, tire ballast. The tires used in this experiment was standard size for the tractor, as specified by the manufacturer, The depth of the tread was more than $85 \%$ of the depth of a new tread. The tires sides was not damaged and the rear tires pressures were adjusted according to the second factor in experiment included $1.1,1.8$ and 2.7 bar . Three tractor speeds were chose carefully $2.35,4.25$ and $6.50 \mathrm{~km} / \mathrm{hr}$ by limited point start treatment length $30 \mathrm{~m}$ and must leftover $10 \mathrm{~m}$ at least before this $30 \mathrm{~m}$ to give tractor ground speeding stability in movement and operation tillage. Then determined time in second by stopwatch to cross tractor these distance (calculated the time tillage for $30 \mathrm{~m}$ only), then calculated by the following equation (7):
$S=D / T \times 3.6$

Where $\mathrm{S}$ was speed measure in $\mathrm{km} / \mathrm{hr}, \mathrm{D}$ was distance treatment line tillage limited equal $30 \mathrm{~m}$, $\mathrm{T}$ was time to cross tractor distance $30 \mathrm{~m}$ in sec, 3.6 was conversion factor.

Operation tillage conducted with $2000 \mathrm{rpm}$ tractor engine by put and control on lever fuel hand for all treatments in these experiment.

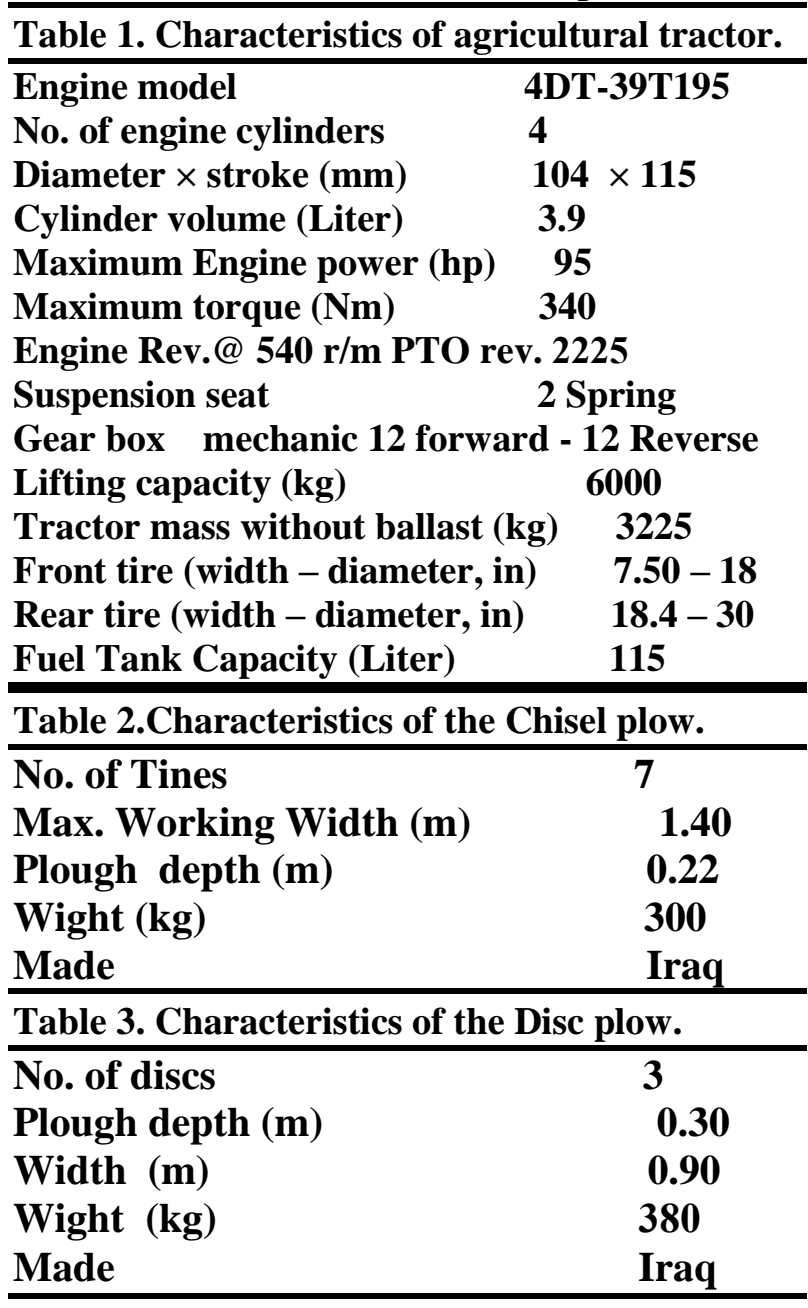

\section{4-1 Measuring Vibration}

Measuring was carried out in real working conditions. The tractor vibration is split two areas, hand-arm and whole body vibration. Hand-arm vibration (HAV) is vibration transmitted into hands and arms when grip steering wheel tractors, Whole-body vibration (WBV) is shaking or jolting of the human body through a supporting surface (usually a seat or the floor such as tractor platform) for example when driving or riding on a tractors. Multiplied vibration levels that occur in a complex system such as tractor are transmitted to the operator in three basic ways (14) : 
-Through the seat, when whole body vibration of the operator is induced.

-Through manual controls and the steering wheel, when vibrations in upper limbs of the operator are induced.

-Through the supports and the floor of the cab as well as foot controls, when mostly local vibration in lower limbs of the operator are induced.

Guidelines for measuring and evaluating human exposure and details of different analysis methods are given in ISO 2631-11997 (13) for the whole-body vibration and ISO 5349-1:2001 (24) for the hand-arm transmitted vibration. In the ISO 5349 recommendations, the most important quantity used to describe the magnitude of the vibration transmitted to the driver's hands is root-mean square frequency-weighted acceleration expressed in $\mathrm{m} / \mathrm{sec}^{2}(25)$. Root mean square is the square root of the arithmetic mean on instantaneous values (amplitude or acceleration) squared. Root mean square acceleration gives the total energy across the entire rang.

The vibration received by drivers dependent on the duration of exposure, Because the exposure patterns may vary, they normalized to a standard reference period. The British Standard refers to an eight hour day and is expressed as $\mathrm{A}(8)$ hours. Other reference periods are used, i.e. International Standard ISO 5349:1989 (26) refers to a 4 hour period and is expressed as A(4) Santia 2014 (27). (Table 4)

Table 4. exposure limits vibration (27).

\begin{tabular}{|l|l|l|l|l|l|}
\hline Working Day (hr) & 8 & 4 & 2 & 1 & $1 / 2$ \\
\hline RMS $^{*} \mathbf{m} / \mathbf{s e c}^{2}$ & 2.5 & 3.5 & 5 & 7 & 10 \\
\hline
\end{tabular}

$*$ RMS Root Mean Square.

In these experiment measured vibration in three location (figure 1):

1- Vibration transmitted to driver hands from steering wheel at three axes horizontal $\mathrm{X}$, lateral $\mathrm{Y}$ and vertical $\mathrm{Z}$.

2-Vibration transmitted to driver feet from platform tractor at three axes horizontal $\mathrm{X}$. lateral $Y$ and vertical $Z$.

3-Vibration in the seat surface at one ordinate vertical $\mathrm{Z}$.

4- Then determine seat effective amplitude transmissibility (SEAT) factor in accordance with ISO 10326-1:1992, 9.1.2 (28), as mention in ISO 5007:2003(29) which adopted by American Society of Agricultural and Biological Engineers (ASABE) May 2006 (30) the SEAT factor is defined as:

$\mathrm{F}_{\text {SEAT }}=\frac{\mathrm{a}_{\mathrm{ws}}}{\mathrm{a}_{\mathrm{wp}}} \quad 2$

Where $F_{\text {SEAT }}$ was seat effective amplitude transmissibility factor, $\mathrm{a}_{\mathrm{ws}}$ was weighted Root Mean Square (RMS) value of the measured vertical acceleration at the seat surface. $a_{w p}$ was weighted Root Mean Square (RMS) value of the measured vertical acceleration at the platform under the seat.

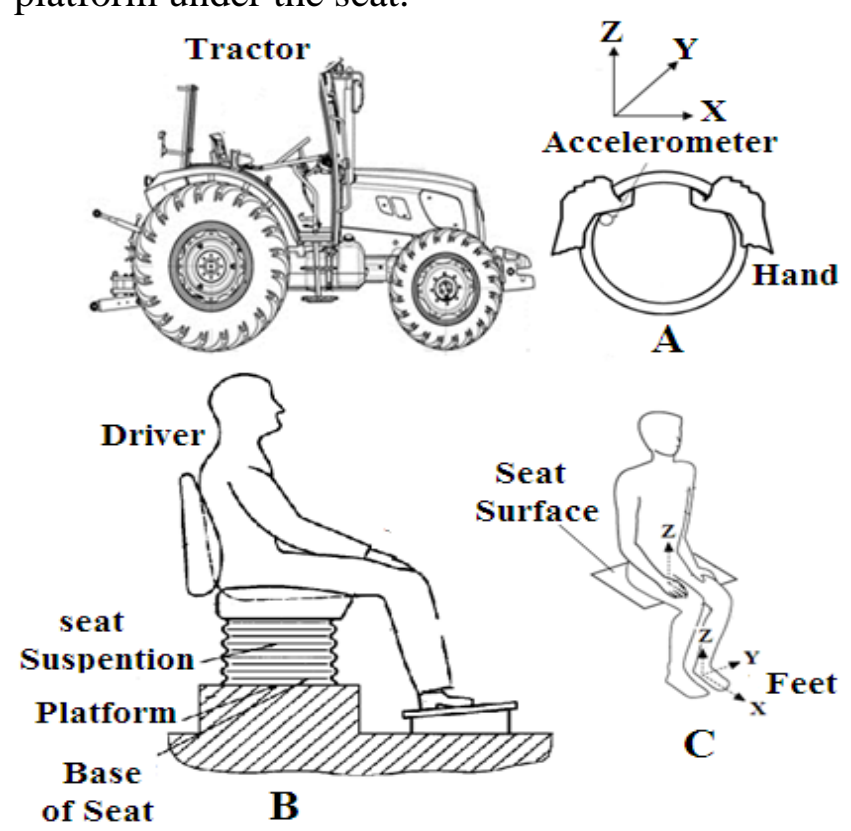

Figure 1.A- Position of the accelerometer on the steering wheel. B - Posture tractor driver's, seat suspension and platform. C- Three dimensions longitudinal $X$, literal $Y$ and vertical $Z$ at feet and vertical $Z$ at seat tractor.

Portable vibration meter type VB-8201HA serial number Q 405638 made in Taiwan (figure 2) was used to measure vibrations in these experiment, before the test, vibration meter was calibrated with another meter to ensure that the obtained data is accurate and reliable. Accelerometer was used to measure the Hand-Arm Vibration (HAV) values of the steering wheel tractor. The accelerometer was secured at a suitable position based on the biodynamic coordinate system and basicentric coordinates of the steering wheel (ISO 53491:2001). The $x$ - and $y$ - axes are the radial and tangential directions of the steering wheel respectively. The $\mathrm{z}$-axis is perpendicular to the $\mathrm{x}-\mathrm{y}$ plane and is positive in the direction towards the steering column (31). 


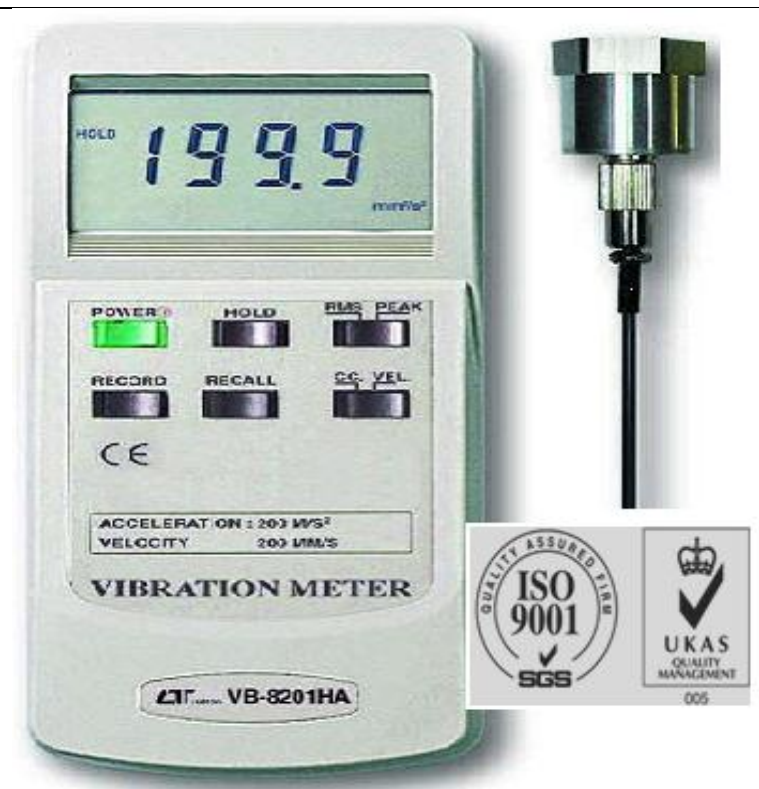

Figure 2 . Vibration meter and sensor . Accelerometer location in TUMOSON tractor 95-80 show in Figure3. The accelerometer is connected to the steering wheel surface by using an adaptor with a clip for the accelerometer, the position of the accelerometer as recommended in ISO 53492:2001 (32) for measuring vibration transmitted in longitudinal $\mathrm{X}$, lateral $\mathrm{Y}$ and vertical $\mathrm{Z}$ directions Hand-Arm Tractor Driver, put the accelerometer in platform tractor to measure vibration transmitted to feet tractor driver in $\mathrm{X}, \mathrm{Y}$ and $\mathrm{Z}$ directions . Finally put accelerometer in the tractor seat to measure vertical vibration in according to ISO 5008:2002 (23).

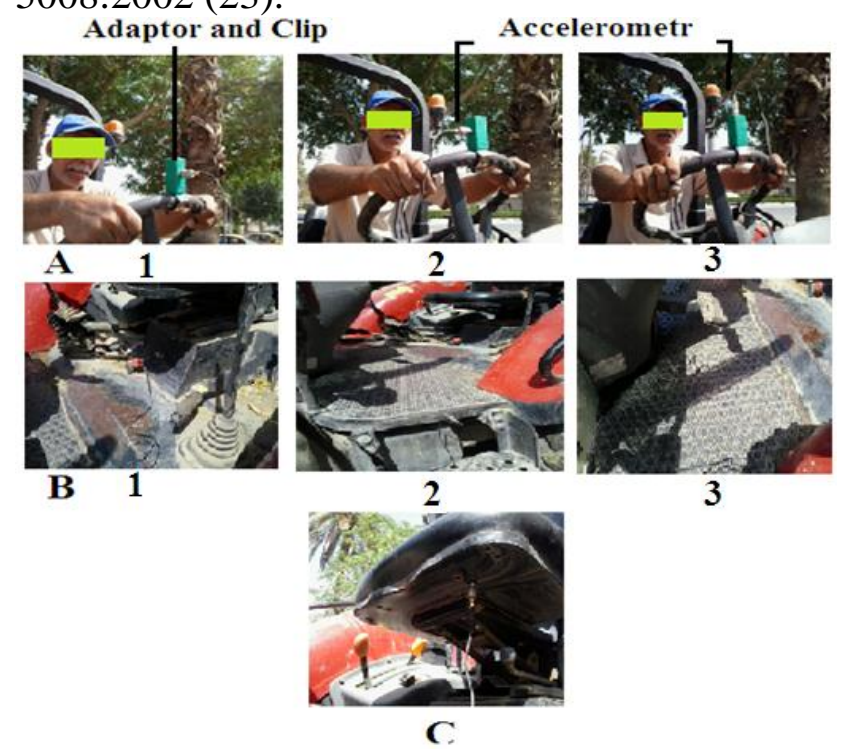

Figure 3. Location accelerometer in TUMOSON tractor 95-80 A/ In steering wheel 1Longitudinal 2-Lateral 3-Virtical. B/ In platform 1- Longitudinal 2-Lateral 3-Virtical. $\mathrm{C} / \mathrm{In}$ Seat to measure vertical vibration.

\section{2-Result and Discussion \\ 2-1 Steering wheel vibration transmitted to hands}

Tables 5, 6 and 7 effects types plows, tires pressure and tillage speeds and interaction on transmitted vibration longitudinal $\mathrm{X}$, lateral $\mathrm{Y}$ and vertical $\mathrm{Z}$ from steering wheel to driver hand. Results show significant effects on the types of plows in transmitted vibration three axes $\mathrm{X}, \mathrm{Y}$ and $\mathrm{Z}$ from steering wheel to driver hand, chisel plow recorded lower values 4.19,3.22 and $4.96 \mathrm{~m} / \mathrm{sec}^{2} \mathrm{X}, \mathrm{Y}$ and $\mathrm{Z}$ as respectively, while disc plow recorded higher values $4.68,3.97$ and $5.50 \mathrm{~m} / \mathrm{sec}^{2}$ as $\mathrm{X}, \mathrm{Y}$ and $\mathrm{Z}$, that may because of the difference figures, actual width, design, method of tillage and penetration between the chisel and disk plows (Figure 4). Result show significant effects on tires pressure in transmitted vibration for three axes $\mathrm{X}, \mathrm{Y}$ and $\mathrm{Z}$ from Steering Wheel to driver hand, tire pressure 1.1 bar recorded lower values was $3.10,2.50$ and $4.15 \mathrm{~m} / \mathrm{sec}^{2}$ as $\mathrm{X}, \mathrm{Y}$ and $\mathrm{Z}$, While 2.7 bar recorded higher values was $5.96,4.96$ and $6.50 \mathrm{~m} / \mathrm{sec}^{2}$ as $\mathrm{X}, \mathrm{Y}$ and $\mathrm{Z}$ (Figure 5), that may because increasing stiffness tires with increasing tires inflation pressure and transmitted vibration will be more with these state, and these result agree with (4 and 19). Result show significant effects on Tillage Speeds in transmitted vibration three axes $\mathrm{X}, \mathrm{Y}$ and $\mathrm{Z}$ from Steering Wheel to Hand Driver, Speed $2.35 \mathrm{~km} / \mathrm{hr}$ recorded lower values were 2.94,2.26 and 3.39 $\mathrm{m} / \mathrm{sec}^{2}$ as $X, Y$ and Z, while speed $6.50 \mathrm{~km} / \mathrm{hr}$ recorded higher values $6.22,5.35$ and 7.25 $\mathrm{m} / \mathrm{sec}^{2}$ (Figure 6), That may be because when increasing speed tractor increasing transmitted vibration, these result agree with $(6,7,8$ and 33). Interaction between chisel plow with tire pressure 1.1 bar recorded lower vibration transmitted in three axes $\mathrm{X}, \mathrm{Y}$ and $\mathrm{Z}$ were $2.77,2.14$ and $3.88 \mathrm{~m} / \mathrm{sec}^{2}$, while Interaction between disc plow with tire pressure 2.7 bar recorded higher vibration transmitted in three axes $\mathrm{X}, \mathrm{Y}$ and $\mathrm{Z}$ were $6.18,5.20$ and 6.83 $\mathrm{m} / \mathrm{sec}^{2}$. Interaction between chisel plow with $2.35 \mathrm{~km} / \mathrm{hr}$ recorded lower vibration transmitted in three axes $\mathrm{X}, \mathrm{Y}$ and $\mathrm{Z}$ were 2.73 , 2.01 and $3.12 \mathrm{~m} / \mathrm{sec}^{2}$, While Interaction between disc plow with $6.50 \mathrm{~km} / \mathrm{hr}$ recorded higher $6.56,5.87$ and $7.51 \mathrm{~m} / \mathrm{sec}^{2}$. Interaction between tires pressure 1.1 bar with tillage 
speeds 2.35 recorded lower vibration transmitted in three axes $\mathrm{X}, \mathrm{Y}$ and $\mathrm{Z}$ were $1.90,1.48$ and $2.38 \mathrm{~m} / \mathrm{sec}^{2}$, while Interaction between tire pressure 2.7 bar with $6.50 \mathrm{~km} / \mathrm{hr}$ recorded higher vibration transmitted in three axes $\mathrm{X}, \mathrm{Y}$ and $\mathrm{Z}$ were 8.05,7.16 and 8.85 $\mathrm{m} / \mathrm{sec}^{2}$. Interaction among chisel plow with tire pressure 1.1 bar with $2.35 \mathrm{~km} / \mathrm{hr}$ recorded lower vibration transmitted in three axes $\mathrm{X}, \mathrm{Y}$ and $\mathrm{Z}$ were $1.66,1.30$ and $2.10 \mathrm{~m} / \mathrm{sec}^{2}$. Interaction between disc plow with tire pressure 2.7 bar with $6.50 \mathrm{~km} / \mathrm{hr}$ recorded higher vibration transmitted in three axes $\mathrm{X}, \mathrm{Y}$ and $\mathrm{Z}$ were $8.43,6.27$ and $9.26 \mathrm{~m} / \mathrm{sec}^{2}$.

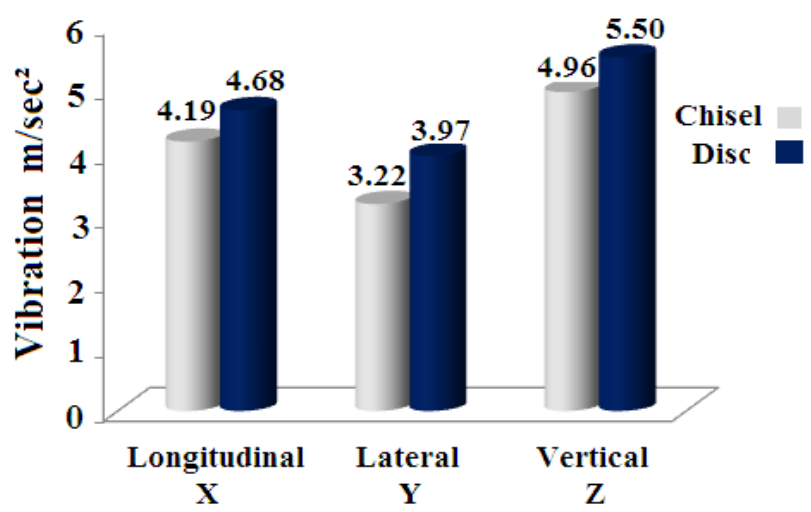

Figure 4.Vibration values in steering wheel during tillage by chisel and disc plows.

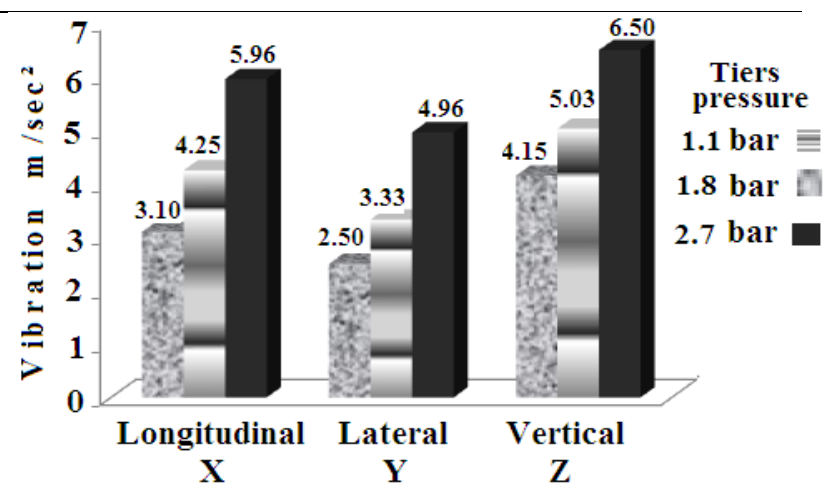

Figure 5.Vibration values in steering wheel during tillage with different Tiers pressure

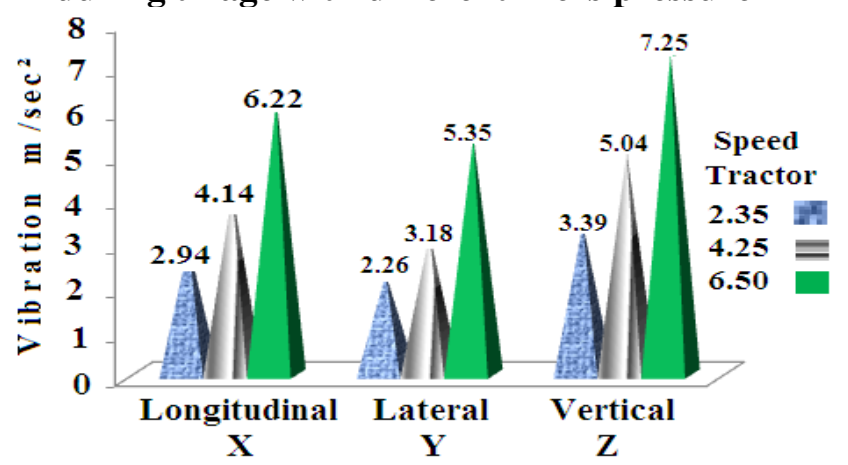

Figure 6.Vibration values in steering wheel during tillage with different tractor speed.

Table 5. Effect types plows, tires pressure, tillage speeds and interaction on transmitted vibration longitudinal $X$ from steering wheel to driver hand.

\begin{tabular}{|l|c|c|c|c|}
\hline \multicolumn{2}{|c|}{ Treatments } & Interaction Plows, Tire Pressure with Tillage Speeds & Interaction Types \\
plows with Tire \\
Pressure
\end{tabular}


Table 6. Effect types plows, tires pressure, tillage speeds and interaction on transmitted vibration lateral $Y$ from steering wheel to driver hand.

\begin{tabular}{|c|c|c|c|c|c|}
\hline \multicolumn{2}{|c|}{ Treatments } & \multirow{2}{*}{\multicolumn{3}{|c|}{$\begin{array}{c}\text { Interaction Plows, Tire Pressure with Tillage } \\
\text { Speeds } \\
\text { Tillage Speed } \mathrm{km} / \mathrm{hr} \\
\end{array}$}} & \multirow{3}{*}{$\begin{array}{l}\text { Interaction Types } \\
\text { plows with Tire } \\
\text { Pressure }\end{array}$} \\
\hline \multirow{2}{*}{$\begin{array}{l}\text { Types } \\
\text { Plows }\end{array}$} & \multirow{2}{*}{$\begin{array}{l}\text { Tire } \\
\text { Pressure } \\
\text { (bar) }\end{array}$} & & & & \\
\hline & & 2.35 & 4.25 & 6.50 & \\
\hline Chisel & $\begin{array}{l}1.1 \\
1.8 \\
2.7\end{array}$ & $\begin{array}{l}1.30 \\
1.80 \\
2.93\end{array}$ & $\begin{array}{l}1.76 \\
2.30 \\
4.46\end{array}$ & $\begin{array}{l}3.36 \\
4.33 \\
6.76\end{array}$ & $\begin{array}{l}2.14 \\
2.81 \\
4.72\end{array}$ \\
\hline Disc & $\begin{array}{l}1.1 \\
1.8 \\
2.7\end{array}$ & $\begin{array}{l}1.66 \\
2.40 \\
2.40\end{array}$ & $\begin{array}{l}2.43 \\
4.63 \\
4.14\end{array}$ & $\begin{array}{l}4.46 \\
7.56 \\
6.27\end{array}$ & $\begin{array}{l}2.85 \\
3.86 \\
5.20\end{array}$ \\
\hline \multicolumn{2}{|c|}{ Tillage Speeds Mean } & 2.26 & 3.18 & 5.35 & \multirow[b]{2}{*}{ Types Plows Mean } \\
\hline \multicolumn{2}{|c|}{ Types Plows } & \multicolumn{3}{|c|}{ Interaction Types plows with Tillage Speeds } & \\
\hline & $\begin{array}{l}\text { hisel } \\
\text { Disc }\end{array}$ & $\begin{array}{l}2.01 \\
2.51\end{array}$ & $\begin{array}{l}2.84 \\
3.53\end{array}$ & $\begin{array}{l}4.82 \\
5.87\end{array}$ & $\begin{array}{l}3.22 \\
3.97\end{array}$ \\
\hline \multicolumn{2}{|c|}{ Tire Pressure (bar) } & \multicolumn{3}{|c|}{ Interaction Tires Pressure with Tillage Speeds } & $\begin{array}{c}\text { Tires Pressure } \\
\text { Mean }\end{array}$ \\
\hline & $\begin{array}{l}1.1 \\
1.8 \\
2.7\end{array}$ & $\begin{array}{l}1.48 \\
2.13 \\
3.16\end{array}$ & $\begin{array}{l}2.10 \\
2.91 \\
4.55\end{array}$ & $\begin{array}{l}3.91 \\
4.96 \\
7.16\end{array}$ & $\begin{array}{l}2.50 \\
3.33 \\
4.96\end{array}$ \\
\hline \multicolumn{6}{|c|}{ Types Plows : 0.196} \\
\hline
\end{tabular}

Table 7. Effect types plows, tires pressure, tillage speeds and interaction on transmitted vibration vertical $\mathrm{Z}$ from steering wheel to driver hand.

\begin{tabular}{|c|c|c|c|c|c|}
\hline \multicolumn{2}{|c|}{ Treatments } & \multirow{2}{*}{\multicolumn{3}{|c|}{$\begin{array}{c}\text { Interaction Plows, Tire Pressure with Tillage Speeds } \\
\text { Tillage Speed } \mathbf{~ k m / h r}\end{array}$}} & \multirow{3}{*}{$\begin{array}{l}\text { Interaction Types } \\
\text { plows with Tire } \\
\text { Pressure }\end{array}$} \\
\hline \multirow{2}{*}{$\begin{array}{l}\text { Types } \\
\text { Plows }\end{array}$} & \multirow{2}{*}{$\begin{array}{c}\text { Tire Pressure } \\
\text { (bar) }\end{array}$} & & & & \\
\hline & & 2.35 & 4.25 & 6.50 & \\
\hline Chisel & $\begin{array}{l}1.1 \\
1.8 \\
2.7\end{array}$ & $\begin{array}{l}2.10 \\
2.93 \\
4.33\end{array}$ & $\begin{array}{l}3.86 \\
4.66 \\
5.76\end{array}$ & $\begin{array}{l}5.70 \\
6.86 \\
8.43\end{array}$ & $\begin{array}{l}3.88 \\
4.82 \\
6.17\end{array}$ \\
\hline Disc & $\begin{array}{l}1.1 \\
1.8 \\
2.7\end{array}$ & $\begin{array}{l}2.66 \\
3.56 \\
4.76\end{array}$ & $\begin{array}{l}4.40 \\
5.10 \\
6.46\end{array}$ & $\begin{array}{l}6.16 \\
7.10 \\
9.26\end{array}$ & $\begin{array}{l}4.41 \\
5.25 \\
6.83\end{array}$ \\
\hline \multicolumn{2}{|c|}{ Tillage Speeds Mean } & 3.39 & 5.04 & 7.25 & \multirow[b]{2}{*}{ Types Plows Mean } \\
\hline \multicolumn{2}{|c|}{ Types Plows } & \multicolumn{3}{|c|}{ Interaction Types plows with Tillage Speeds } & \\
\hline & $\begin{array}{l}\text { Chisel } \\
\text { Disc }\end{array}$ & $\begin{array}{l}3.12 \\
3.66\end{array}$ & $\begin{array}{l}4.76 \\
5.32\end{array}$ & $\begin{array}{l}7.00 \\
7.51\end{array}$ & $\begin{array}{l}4.96 \\
5.50\end{array}$ \\
\hline \multicolumn{2}{|c|}{ Tire Pressure (bar) } & \multicolumn{3}{|c|}{ Interaction Tires Pressure with Tillage Speeds } & Tires Pressure Mean \\
\hline & $\begin{array}{l}1.1 \\
1.8 \\
2.7\end{array}$ & $\begin{array}{l}2.38 \\
3.25 \\
4.55\end{array}$ & $\begin{array}{l}4.13 \\
4.88 \\
6.11\end{array}$ & \begin{tabular}{r|}
5.93 \\
6.98 \\
8.85
\end{tabular} & $\begin{array}{l}4.15 \\
5.03 \\
6.50\end{array}$ \\
\hline \multicolumn{6}{|c|}{$\begin{array}{cc}\text { Types Plows : } \mathbf{0 . 1 6 4 1} & \text { Tillage Pressure }: 0.2009 \\
\text { Interaction Types Plows with Tires Pressure }: 1.6549 \\
\text { Interaction Types Plows with Tillage Speeds }: 1.0455 \\
\text { Interaction Tires Pressure with Tillage Speeds }: 0.4781 \\
\text { Interaction Types Plows ,Tires Pressure with Tillage Speeds: } 0.4922\end{array}$} \\
\hline
\end{tabular}




\section{2-2 Vibration transmitted on driver feet from tractor platform}

Tables 8, 9 and 10 effects types plows, tires pressure, tillage speeds and interaction on transmitted vibration longitudinal $\mathrm{X}$, lateral $\mathrm{Y}$ and vertical $\mathrm{Z}$ from Platform on Feet driver. Results show significant effects on the types of plows in transmitted vibration for three axes $\mathrm{X}, \mathrm{Y}$ and $\mathrm{Z}$ from tractor platform to driver feet, chisel plow recorded lower values 7.56,6.18 and $6.81 \mathrm{~m} / \mathrm{sec}^{2} \mathrm{~L}, \mathrm{Y}$ and $\mathrm{Z}$ respectively, while disc plow recorded 8.23,7.84 and $7.62 \mathrm{~m} / \mathrm{sec}^{2}$ as $\mathrm{X}, \mathrm{Y}$ and $\mathrm{Z}$ (Figure 7), that may because of the difference figures plows, actual width, design, principal of tillage and method of penetration between the chisel and disc plows. Result show significant effects on tires pressure in transmitted vibration three axes $\mathrm{X}, \mathrm{Y}$ and $\mathrm{Z}$ from tractor platform to driver feet, tire pressure 1.1 bar recorded lower values was $6.78,5.93$ and $6.22 \mathrm{~m} / \mathrm{sec}^{2}$ as $\mathrm{X}, \mathrm{Y}$ and $\mathrm{Z}$, While 2.7 bar recorded higher values 9.26,8.28 and $8.23 \mathrm{~m} / \mathrm{sec}^{2}$ as X,Y and Z (Figure 8), that may because increasing stiffness tires with increasing tires inflation pressure and transmitted vibration will be more with these state, these result agree with (18, 34 and 35). Result show significant effects on tillage speeds in transmitted vibration three axes $X, Y$ and $\mathrm{Z}$ from platform feet driver, speed 2.35 $\mathrm{km} / \mathrm{hr}$ recorded lower values were $6.20,5.75$ and $5.82 \mathrm{~m} / \mathrm{sec}^{2}$ as $\mathrm{X}, \mathrm{Y}$ and $\mathrm{Z}$, while speed $6.50 \mathrm{~km} / \mathrm{hr}$ recorded higher values $9.76,8.38$ and $8.97 \mathrm{~m} / \mathrm{sec}^{2}$ (Figure 9), That may be because when increasing tractor speed increasing transmitted vibration from soil to Tires then to tractor platform, and these result agree with (4 and 12). Interaction between chisel plow with tire pressure 1.1 bar recorded lower vibration transmitted in three axes $\mathrm{X}, \mathrm{Y}$ and $\mathrm{Z}$ were $6.40,5.32$ and $5.74 \mathrm{~m} / \mathrm{sec}^{2}$, while Interaction between disc plow with tire pressure 2.7 bar recorded higher vibration transmitted in three axes $\mathrm{X}, \mathrm{Y}$ and $\mathrm{Z}$ were 9.51 , 9.32 and $8.66 \mathrm{~m} / \mathrm{sec}^{2}$. Interaction between chisel plow with $2.35 \mathrm{~km} / \mathrm{hr}$ recorded lower vibration transmitted in three axes $\mathrm{X}, \mathrm{Y}$ and $\mathrm{Z}$ were $5.78,4.96$ and $5.52 \mathrm{~m} / \mathrm{sec}^{2}$, while Interaction between disc plow with 6.50 $\mathrm{km} / \mathrm{hr}$ recorded higher $10.10,9.20$ and 9.35 $\mathrm{m} / \mathrm{sec}^{2}$. Interaction between tires pressure 1.1 bar with tillage speeds 2.35 recorded lower vibration transmitted in three axes $\mathrm{X}, \mathrm{Y}$ and $\mathrm{Z}$ were $5.30,4.80$ and $4.75 \mathrm{~m} / \mathrm{sec}^{2}$, while Interaction between tire pressure 2.7 bar with $6.50 \mathrm{~km} / \mathrm{hr}$ recorded higher vibration transmitted in three axes $\mathrm{X}, \mathrm{Y}$ and $\mathrm{Z}$ were $11.31,9.85$ and $10.06 \mathrm{~m} / \mathrm{sec}^{2}$. Interaction between Chisel plow with tire pressure $1.1 \mathrm{bar}$ with $2.35 \mathrm{~km} / \mathrm{hr}$ recorded lower vibration transmitted in three axes $\mathrm{X}, \mathrm{Y}$ and $\mathrm{Z}$ were 4.83 , 4.30 and $4.36 \mathrm{~m} / \mathrm{sec}^{2}$, while Interaction between disc plow with tire pressure 2.7 bar with $6.50 \mathrm{~km} / \mathrm{hr}$ recorded higher vibration transmitted in three axes $\mathrm{X}, \mathrm{Y}$ and $\mathrm{Z}$ were $11.70,10.83$ and $10.36 \mathrm{~m} / \mathrm{sec}^{2}$.

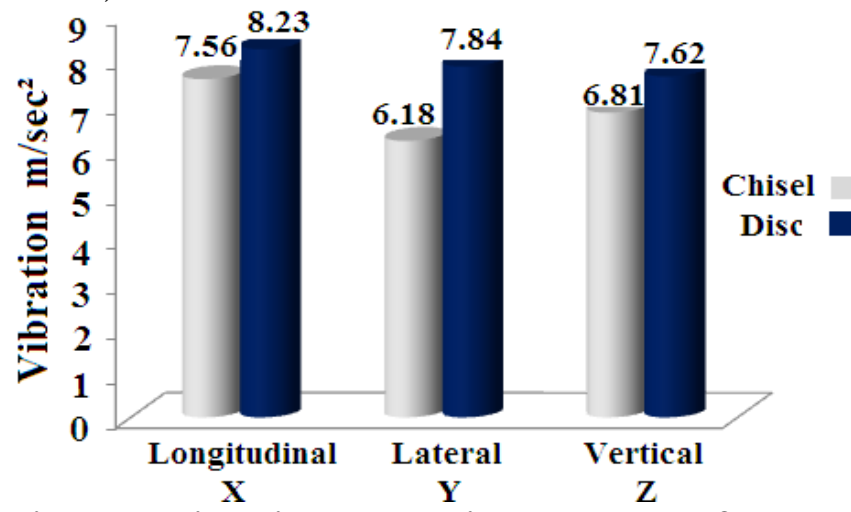

Figure 7.Vibration values in tractor platform during tillage by chisel and disc plows.

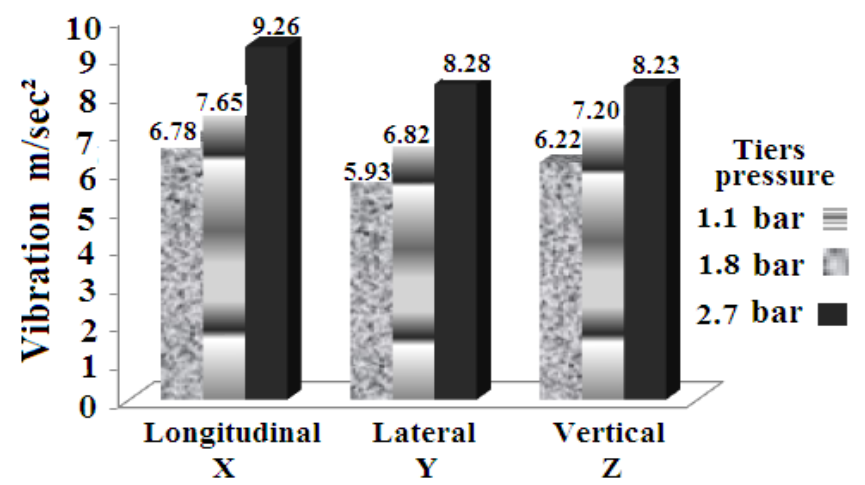

Figure 8.Vibration values in tractor platform during tillage with different tiers pressure.

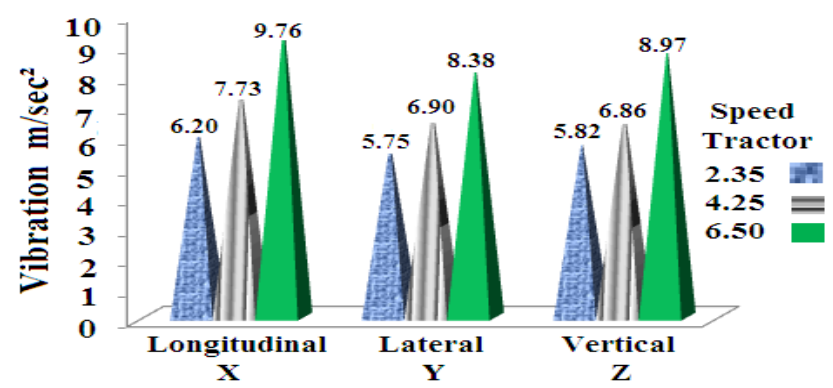

Figure 9.Vibration values in tractor platform during tillage with different tractor speed. 
Table 8. Effect types plows, tires pressure, tillage speeds and interaction on vibration transmitted longitudinal $\mathbf{X}$ from platform to driver feet.

\begin{tabular}{|c|c|c|c|c|c|}
\hline \multicolumn{2}{|c|}{ Treatments } & \multirow{2}{*}{\multicolumn{3}{|c|}{$\begin{array}{c}\text { Interaction Plows, Tire Pressure with Tillage Speeds } \\
\text { Tillage Speed } \mathrm{km} / \mathrm{hr}\end{array}$}} & \multirow{3}{*}{$\begin{array}{l}\text { Interaction Types } \\
\text { plows with Tire } \\
\text { Pressure }\end{array}$} \\
\hline \multirow{2}{*}{$\begin{array}{l}\text { Types } \\
\text { Plows }\end{array}$} & \multirow{2}{*}{$\begin{array}{l}\text { Tire Pressure } \\
\text { (bar) }\end{array}$} & & & & \\
\hline & & 2.35 & 4.25 & 6.50 & \\
\hline Chisel & $\begin{array}{l}1.1 \\
1.8 \\
2.7\end{array}$ & $\begin{array}{l}4.83 \\
5.60 \\
6.93\end{array}$ & $\begin{array}{l}6.23 \\
7.03 \\
9.20\end{array}$ & $\begin{array}{c}8.13 \\
9.20 \\
10.93\end{array}$ & $\begin{array}{l}6.40 \\
7.27 \\
9.02\end{array}$ \\
\hline Disc & $\begin{array}{l}1.1 \\
1.8 \\
2.7\end{array}$ & $\begin{array}{l}5.76 \\
6.43 \\
7.63\end{array}$ & $\begin{array}{l}6.86 \\
7.90 \\
9.20\end{array}$ & $\begin{array}{c}8.86 \\
9.73 \\
11.70\end{array}$ & $\begin{array}{l}7.16 \\
8.02 \\
9.51\end{array}$ \\
\hline \multicolumn{2}{|c|}{ Tillage Speeds Mean } & 6.20 & $\mathbf{7 . 7 3}$ & 9.76 & \multirow[b]{2}{*}{ Types Plows Mean } \\
\hline \multicolumn{2}{|c|}{ Types Plows } & \multicolumn{3}{|c|}{ Interaction Types plows with Tillage Speeds } & \\
\hline & $\begin{array}{l}\text { Chisel } \\
\text { Disc }\end{array}$ & $\begin{array}{l}5.78 \\
6.61\end{array}$ & $\begin{array}{l}7.48 \\
7.98\end{array}$ & $\begin{array}{c}9.42 \\
10.10\end{array}$ & $\begin{array}{l}7.56 \\
8.23\end{array}$ \\
\hline \multicolumn{2}{|c|}{ Tire Pressure (bar) } & \multicolumn{3}{|c|}{ Interaction Tires Pressure with Tillage Speeds } & Tires Pressure Mean \\
\hline & $\begin{array}{l}1.1 \\
1.8 \\
2.7\end{array}$ & $\begin{array}{l}5.30 \\
6.01 \\
7.28\end{array}$ & $\begin{array}{l}6.55 \\
7.46 \\
9.20\end{array}$ & $\begin{array}{c}8.50 \\
9.46 \\
11.31\end{array}$ & $\begin{array}{l}6.78 \\
7.65 \\
9.26\end{array}$ \\
\hline \multicolumn{6}{|c|}{$\begin{array}{l}\text { L.S.D } 0.05 \\
\text { Types Plows : } 0.1513 \quad \text { Tires Pressure }: 0.1854 \\
\text { Interaction Types Plows with Tires Pressure }: 1.5283 \\
\text { Interaction Types Plows with Tillage Speeds }: 1.0986 \\
\text { Interaction Tires Pressure with Tillage Speeds }: 0.5465 \\
\text { Interaction Types Plows, Tires Pressure with Tillage Speeds: } \mathbf{0 . 4 5 4}\end{array}$} \\
\hline
\end{tabular}

Table 9. Effect types plows, tires pressure, tillage speeds and interaction on vibration transmitted literal Y from platform to driver feet.

\begin{tabular}{|c|c|c|c|c|c|}
\hline \multicolumn{2}{|c|}{ Treatments } & \multicolumn{3}{|c|}{$\begin{array}{l}\text { Interaction Plows, Tire Pressure with Tillage } \\
\text { Speeds }\end{array}$} & \multirow{3}{*}{$\begin{array}{c}\text { Interaction Types } \\
\text { plows with Tire } \\
\text { Pressure }\end{array}$} \\
\hline \multirow{2}{*}{$\begin{array}{l}\text { Types } \\
\text { Plows }\end{array}$} & \multirow{2}{*}{$\begin{array}{l}\text { Tire } \\
\text { Pressure } \\
\text { (bar) }\end{array}$} & \multicolumn{3}{|c|}{ Tillage Speed km/hr } & \\
\hline & & 2.35 & 4.25 & 6.50 & \\
\hline Chisel & $\begin{array}{l}1.1 \\
1.8 \\
2.7\end{array}$ & $\begin{array}{l}4.30 \\
4.76 \\
5.83\end{array}$ & $\begin{array}{l}5.10 \\
5.86 \\
7.03\end{array}$ & $\begin{array}{l}6.56 \\
7.30 \\
8.86\end{array}$ & \begin{tabular}{|l|}
5.32 \\
5.97 \\
7.24
\end{tabular} \\
\hline Disc & $\begin{array}{l}1.1 \\
1.8 \\
2.7\end{array}$ & $\begin{array}{l}5.30 \\
6.40 \\
7.90\end{array}$ & $\begin{array}{l}6.50 \\
7.70 \\
9.23\end{array}$ & $\begin{array}{c}7.83 \\
8.93 \\
10.83\end{array}$ & $\begin{array}{l}6.54 \\
7.67 \\
9.32\end{array}$ \\
\hline \multicolumn{2}{|c|}{ Tillage Speeds Mean } & 5.75 & 6.90 & 8.38 & \multirow[b]{2}{*}{ Types Plows Mean } \\
\hline \multicolumn{2}{|c|}{ Types Plows } & \multicolumn{3}{|c|}{ Interaction Types plows with Tillage Speeds } & \\
\hline & $\begin{array}{l}\text { Chisel } \\
\text { Disc }\end{array}$ & $\begin{array}{l}4.96 \\
6.53\end{array}$ & $\begin{array}{l}6.00 \\
7.81\end{array}$ & $\begin{array}{l}7.57 \\
9.20\end{array}$ & $\begin{array}{l}6.18 \\
7.84\end{array}$ \\
\hline \multicolumn{2}{|c|}{ Tire Pressure (bar) } & \multicolumn{3}{|c|}{ Interaction Tires Pressure with Tillage Speeds } & $\begin{array}{l}\text { Tires Pressure } \\
\text { Mean }\end{array}$ \\
\hline & $\begin{array}{l}1.1 \\
1.8 \\
2.7\end{array}$ & $\begin{array}{l}4.80 \\
5.58 \\
6.86\end{array}$ & $\begin{array}{l}5.80 \\
6.78 \\
8.13\end{array}$ & $\begin{array}{l}7.20 \\
8.11 \\
9.85\end{array}$ & $\begin{array}{l}5.93 \\
6.82 \\
8.28\end{array}$ \\
\hline \multicolumn{6}{|c|}{$\begin{array}{l}\text { L.S.D } 0.05 \\
\text { Types Plows }: 0.1696 \quad \text { Tires Pressure }: 0.2077\end{array}$} \\
\hline
\end{tabular}


Table 10. Effect types plows, tires pressure, tillage speeds and interaction on vibration transmitted vertical $\mathrm{Z}$ from platform to driver feet.

\begin{tabular}{|c|c|c|c|c|c|}
\hline \multicolumn{2}{|c|}{ Treatments } & \multirow{2}{*}{\multicolumn{3}{|c|}{$\begin{array}{c}\text { Interaction Plows, Tire Pressure with Tillage Speeds } \\
\text { Tillage Speed } \mathrm{km} / \mathrm{hr}\end{array}$}} & \multirow{3}{*}{$\begin{array}{l}\text { Interaction Types } \\
\text { plows with Tire } \\
\text { Pressure }\end{array}$} \\
\hline \multirow{2}{*}{$\begin{array}{l}\text { Types } \\
\text { Plows }\end{array}$} & \multirow{2}{*}{$\begin{array}{l}\text { Tire Pressure } \\
\quad \text { (bar) }\end{array}$} & & & & \\
\hline & & 2.35 & 4.25 & $\mathbf{6 . 5 0}$ & \\
\hline Chisel & $\begin{array}{l}1.1 \\
1.8 \\
2.7\end{array}$ & $\begin{array}{l}4.36 \\
5.26 \\
6.93\end{array}$ & $\begin{array}{l}5.43 \\
6.83 \\
6.73\end{array}$ & $\begin{array}{l}7.43 \\
8.56 \\
9.76\end{array}$ & $\begin{array}{l}5.74 \\
6.88 \\
7.81\end{array}$ \\
\hline Disc & $\begin{array}{l}1.1 \\
1.8 \\
2.7\end{array}$ & $\begin{array}{l}5.13 \\
5.96 \\
7.30\end{array}$ & $\begin{array}{l}6.46 \\
7.36 \\
8.33\end{array}$ & $\begin{array}{c}8.50 \\
9.20 \\
10.36\end{array}$ & $\begin{array}{l}6.70 \\
7.51 \\
8.66\end{array}$ \\
\hline \multicolumn{2}{|c|}{ Tillage Speeds Mean } & 5.82 & 6.86 & 8.97 & \multirow[b]{2}{*}{ Types Plows Mean } \\
\hline \multicolumn{2}{|c|}{ Types Plows } & \multicolumn{3}{|c|}{ Interaction Types plows with Tillage Speeds } & \\
\hline & $\begin{array}{l}\text { Chisel } \\
\text { Disc }\end{array}$ & $\begin{array}{l}5.52 \\
6.13\end{array}$ & $\begin{array}{l}6.33 \\
7.38\end{array}$ & $\begin{array}{l}8.58 \\
9.35\end{array}$ & $\begin{array}{l}6.81 \\
7.62\end{array}$ \\
\hline \multicolumn{2}{|c|}{ Tire Pressure (bar) } & \multicolumn{3}{|c|}{ Interaction Tires Pressure with Tillage Speeds } & Tires Pressure Mean \\
\hline & $\begin{array}{l}1.1 \\
1.8\end{array}$ & $\begin{array}{l}4.75 \\
5.61\end{array}$ & 5.95 & $\begin{array}{l}7.96 \\
8.88\end{array}$ & 6.22 \\
\hline & 2.7 & 7.11 & $\mathbf{7 . 5 3}$ & 10.06 & 8.23 \\
\hline
\end{tabular}

L.S.D $\quad 0.05$

Types Plows : $0.3366 \quad$ Tires Pressure : 0.4123

Interaction Types Plows with Tires Pressure : 1.4565

Interaction Types Plows with Tillage Speeds : 1.0121

Interaction Tires Pressure with Tillage Speeds : 0.8539

Interaction Types Plows ,Tires Pressure with Tillage Speeds: 1.0098

\section{3-2 Vertical vibration transmitte to seat tractor}

Table 11. Effect type plows, tires pressure, tillage speeds and interaction on transmitted vibration vertical $\mathrm{Z}$ in seat tractor. Results show significant effects on types of plows in transmitted vibration vertical $\mathrm{Z}$ in seat tractor , chisel plow recorded lower value 3.30 $\mathrm{m} / \mathrm{sec}^{2}$, while disc plow recorded $3.63 \mathrm{~m} / \mathrm{sec}^{2}$ (Figure 10), that may be because different figure plow, design and width plows. Result show significant effect to tires pressure in transmitted vertical vibration $\mathrm{Z}$ in seat tractor , tire pressure 1.1 bar recorded lower values was $2.85 \mathrm{~m} / \mathrm{sec}^{2}$, while 2.7 bar recorded higher values was 4.16 , that may because increasing stiffness tires with increasing tires inflation pressure and transmitted vibration will be more with these state, and these result agree with $(4,18,34)$. Result show significant effects tillage speeds in transmitted vertical vibration, speed $2.35 \mathrm{~km} / \mathrm{hr}$ recorded lower values were $2.47 \mathrm{~m} / \mathrm{sec}^{2}$ as , while speed 6.50 $\mathrm{km} / \mathrm{hr}$ recorded higher value $4.61 \mathrm{~m} / \mathrm{sec}^{2}$, that may be because when increasing tractor speed increasing transmitted vibration, and these result agree with (1). Interaction between chisel plow with tire pressure 1.1 bar recorded lower vertical vibration transmitted 2.65 $\mathrm{m} / \mathrm{sec}^{2}$, while Interaction between disc plow with tire pressure 2.7 bar recorded higher vibration transmitted $4.32 \mathrm{~m} / \mathrm{sec}^{2}$. Interaction between chisel plow with $2.35 \mathrm{~km} / \mathrm{hr}$ recorded lower vibration transmitted $2.30 \mathrm{~m} / \mathrm{sec}^{2}$, while interaction between disc plow with $6.50 \mathrm{~km} / \mathrm{hr}$ recorded higher $4.75 \mathrm{~m} / \mathrm{sec}^{2}$. Interaction between tire pressure 1.1 bar with tillage speeds 2.35 recorded lower vibration transmitted $1.88 \mathrm{~m} / \mathrm{sec}^{2}$, while interaction between tire pressure 2.7 bar with $6.50 \mathrm{~km} / \mathrm{hr}$ recorded higher vibration transmitted $5.30 \mathrm{~m} / \mathrm{sec}^{2}$. interaction between chisel plow with tire pressure 1.1 bar with $2.35 \mathrm{~km} / \mathrm{hr}$ recorded lower vibration transmitted $1.70 \mathrm{~m} / \mathrm{sec}^{2}$, while Interaction between disc plow with tire pressure 2.7 bar with $6.50 \mathrm{~km} / \mathrm{hr}$ recorded higher vibration transmitted $5.46 \mathrm{~m} / \mathrm{sec}^{2}$.

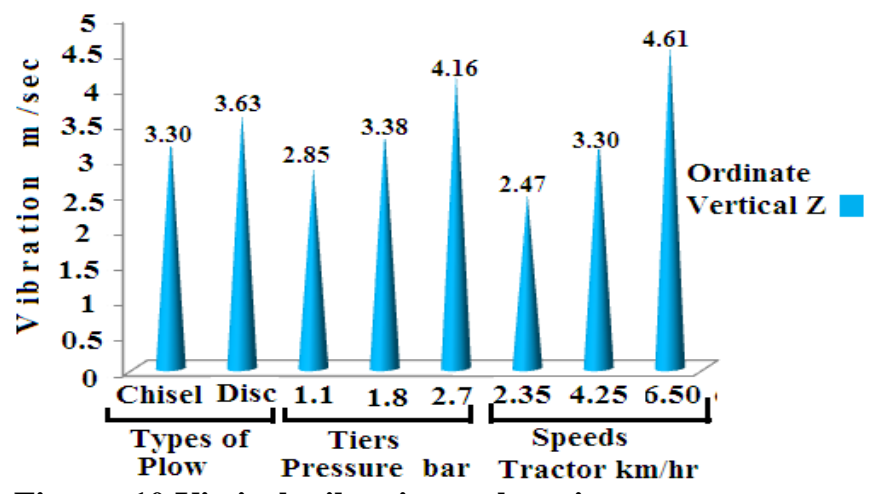

Figure 10.Virtical vibration values in seat tractor during tillage with plows, tiers pressure and different tractor speed. 
Table 11. Effect types plows, tires pressure and tillage speeds and interaction on vibration vertical $\mathrm{Z}$ in tractor seat .

\begin{tabular}{|c|c|c|c|c|c|}
\hline \multicolumn{2}{|c|}{ Treatments } & \multirow{2}{*}{\multicolumn{3}{|c|}{$\begin{array}{c}\text { Interaction Plows, Tire Pressure with Tillage } \\
\text { Speeds }\end{array}$}} & \multirow{3}{*}{$\begin{array}{c}\text { Interaction Types } \\
\text { plows with Tire } \\
\text { Pressure }\end{array}$} \\
\hline \multirow{2}{*}{$\begin{array}{l}\text { Types } \\
\text { Plows }\end{array}$} & \multirow{2}{*}{$\begin{array}{c}\text { Tire } \\
\text { Pressure } \\
\text { (bar) }\end{array}$} & & & & \\
\hline & & 2.35 & 4.25 & 6.50 & \\
\hline Chisel & $\begin{array}{l}1.1 \\
1.8 \\
2.7\end{array}$ & $\begin{array}{l}1.70 \\
2.20 \\
3.00\end{array}$ & $\begin{array}{l}2.40 \\
3.10 \\
3.86\end{array}$ & $\begin{array}{l}3.86 \\
4.43 \\
5.13\end{array}$ & $\begin{array}{l}2.65 \\
3.24 \\
4.00\end{array}$ \\
\hline Disc & $\begin{array}{l}1.1 \\
1.8 \\
2.7\end{array}$ & $\begin{array}{l}2.06 \\
2.50 \\
3.40\end{array}$ & $\begin{array}{l}2.96 \\
3.40 \\
4.10 \\
\end{array}$ & $\begin{array}{l}4.10 \\
4.70 \\
5.46 \\
\end{array}$ & $\begin{array}{l}3.04 \\
3.53 \\
4.32 \\
\end{array}$ \\
\hline \multicolumn{2}{|c|}{ Tillage Speeds Mean } & 2.47 & 3.30 & 4.61 & \multirow[b]{2}{*}{ Types Plows Mean } \\
\hline \multicolumn{2}{|c|}{ Types Plows } & \multicolumn{3}{|c|}{ Interaction Types plows with Tillage Speeds } & \\
\hline & $\begin{array}{l}\text { hisel } \\
\text { Disc }\end{array}$ & $\begin{array}{l}2.30 \\
2.65\end{array}$ & $\begin{array}{l}3.12 \\
3.48\end{array}$ & $\begin{array}{l}4.47 \\
4.75\end{array}$ & $\begin{array}{l}3.30 \\
3.63\end{array}$ \\
\hline \multicolumn{2}{|c|}{ Tire Pressure (bar) } & \multicolumn{3}{|c|}{ Interaction Tires Pressure with Tillage Speeds } & $\begin{array}{c}\text { Tires Pressure } \\
\text { Mean }\end{array}$ \\
\hline & $\begin{array}{l}1.1 \\
1.8 \\
2.7\end{array}$ & $\begin{array}{l}1.88 \\
2.35 \\
3.20\end{array}$ & $\begin{array}{l}2.68 \\
3.25 \\
3.98\end{array}$ & $\begin{array}{l}3.98 \\
4.56 \\
5.30\end{array}$ & $\begin{array}{l}2.85 \\
3.38 \\
4.16\end{array}$ \\
\hline \multicolumn{6}{|c|}{$\begin{array}{l}\text { L.S.D } 0.05 \\
\text { Types Plows : } 0.1001 \quad \text { Tires Pressure }: 0.1226 \\
\text { Interaction Types Plows with Tires Pressure }: 0.9188 \\
\text { Interaction Types Plows with Tillage Speeds }: 0.575 \\
\text { Interaction Tires Pressure with Tillage Speeds }: 0.2941 \\
\text { Interaction Types Plows ,Tires Pressure with Tillage Spe }\end{array}$} \\
\hline
\end{tabular}

\section{4 -2 Seat Effective Amplitude Transmissibility ( SEAT ) Factor}

Table 10. Effect types plows, tires pressure, tillage speeds and interaction on Seat Effective Amplitude Transmissibility (SEAT) Factor . Results show no significant effects to the types of plows in SEAT Factor. Result show significant effect on tires pressure in SEAT Factor (Figure 11), tire pressure 1.1 bar recorded lower factor 0.4497, while tire pressure 2.7 bar recorded higher factor 0.4872 , may be because these result depend of values vertical vibration in seat tractor and plat form as equation 2. Result show significant effects on tillage speeds in SEAT Factor, speed 2.35 $\mathrm{km} / \mathrm{hr}$ recorded lower factor 0.4216 , while speed $6.50 \mathrm{~km} / \mathrm{hr}$ recorded higher factor 0.5139 . Interaction between chisel plow with tire pressure 1.1 bar recorded lower SEAT Factor 0.4505 , while Interaction between disc plow with tire pressure 2.7 bar recorded higher factor 0.4950 . Interaction between chisel plow with $2.35 \mathrm{~km} / \mathrm{hr}$ recorded lower factor 0.4139 , while Interaction between disc plow with 6.50 $\mathrm{km} / \mathrm{hr}$ recorded higher 0.5069 . Interaction between tires pressure 1.1 bar with tillage speeds 2.35 recorded lower SEAT Factor 0.3962 , while Interaction between tire pressure 2.7 bar with $6.50 \mathrm{~km} / \mathrm{hr}$ recorded higher 0.5264 . Interaction between chisel plow with tire pressure 1.1 bar with $2.35 \mathrm{~km} / \mathrm{hr}$ recorded lower SEAT Factor 0.3900, while Interaction between disk plow with tire pressure 2.7 bar with $6.50 \mathrm{~km} / \mathrm{hr}$ recorded higher 0.5139 .

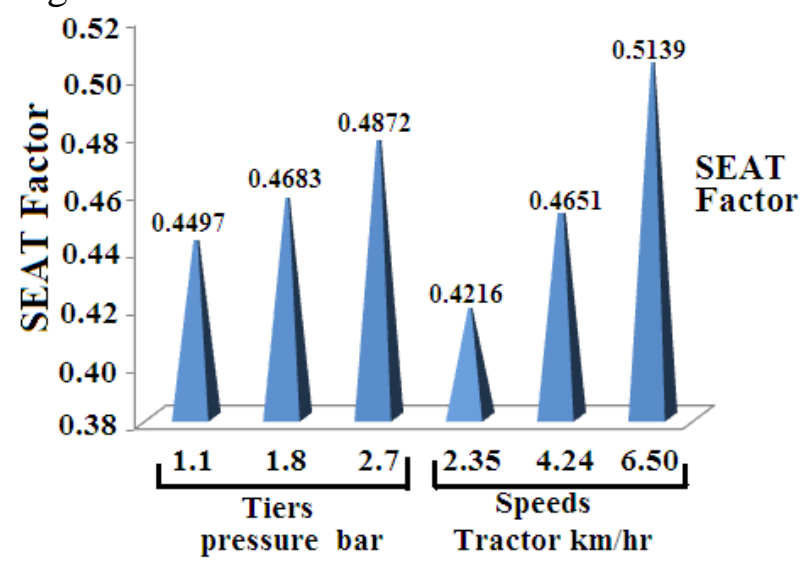

Figure 11. Seat Effective Amplitude Transmissibility (SEAT) Factor during tillage with different tiers pressure and tractor speed. 
Table 12. Effect types plows, tires pressure, tillage speeds and interaction on Seat Effective Amplitude Transmissibility (SEAT) Factor .

\begin{tabular}{|c|c|c|c|c|c|}
\hline \multicolumn{2}{|c|}{ Treatments } & \multirow{2}{*}{\multicolumn{3}{|c|}{$\begin{array}{c}\text { Interaction Plows, Tire Pressure with Tillage Speeds } \\
\text { Tillage Speed } \mathrm{km} / \mathrm{hr}\end{array}$}} & \multirow{3}{*}{$\begin{array}{l}\text { Interaction Types } \\
\text { plows with Tire } \\
\text { Pressure }\end{array}$} \\
\hline \multirow{2}{*}{$\begin{array}{l}\text { Types } \\
\text { Plows }\end{array}$} & \multirow{2}{*}{$\begin{array}{l}\text { Tire Pressure } \\
\text { (bar) }\end{array}$} & & & & \\
\hline & & 2.35 & 4.25 & 6.50 & \\
\hline Chisel & $\begin{array}{l}1.1 \\
1.8 \\
2.7\end{array}$ & $\begin{array}{l}0.3900 \\
0.4185 \\
0.4331\end{array}$ & $\begin{array}{l}0.4419 \\
0.4536 \\
0.4796\end{array}$ & $\begin{array}{l}0.5254 \\
0.5178 \\
0.5254\end{array}$ & \begin{tabular}{|l|}
0.4505 \\
0.4633 \\
0.4794
\end{tabular} \\
\hline Disc & $\begin{array}{l}1.1 \\
1.8 \\
2.7\end{array}$ & $\begin{array}{l}0.4025 \\
0.4202 \\
0.4331\end{array}$ & $\begin{array}{l}0.4614 \\
0.4619 \\
0.4921\end{array}$ & $\begin{array}{l}0.4825 \\
0.5109 \\
0.5273\end{array}$ & $\begin{array}{l}0.4488 \\
0.4643 \\
0.4950\end{array}$ \\
\hline \multicolumn{2}{|c|}{ Tillage Speeds Mean } & 0.4216 & 0.4651 & 0.5139 & \multirow[b]{2}{*}{ Types Plows Mean } \\
\hline \multicolumn{2}{|c|}{ Types Plows } & \multicolumn{3}{|c|}{ Interaction Types plows with Tillage Speeds } & \\
\hline & $\begin{array}{l}\text { Chisel } \\
\text { Disc }\end{array}$ & $\begin{array}{l}0.4139 \\
0.4294\end{array}$ & $\begin{array}{l}0.4584 \\
0.4718\end{array}$ & $\begin{array}{l}0.5209 \\
0.5069\end{array}$ & $\begin{array}{l}0.4644 \\
0.4694\end{array}$ \\
\hline \multicolumn{2}{|c|}{ Tire Pressure (bar) } & \multicolumn{3}{|c|}{ Interaction Tires Pressure with Tillage Speeds } & Tires Pressure Mean \\
\hline & $\begin{array}{l}1.1 \\
1.8 \\
2.7\end{array}$ & $\begin{array}{l}0.3962 \\
0.4194 \\
0.4494\end{array}$ & $\begin{array}{l}0.4516 \\
0.4578 \\
0.4858\end{array}$ & $\begin{array}{l}0.5011 \\
0.6143 \\
0.5264\end{array}$ & $\begin{array}{l}0.4497 \\
0.4638 \\
0.4872\end{array}$ \\
\hline \multicolumn{6}{|c|}{$\begin{array}{lcc}\text { L.S.D } 0.05 & & \\
\text { Types Plows }: \text { N.S } & \text { Tires Pressure }: 0.0174 & \text { Tillage Speeds }: 0.0174 \\
\text { Interaction Types Plows with Tires Pressure }: \mathbf{0 . 0 4 5 2} & \\
\text { Interaction Types Plows with Tillage Speeds }: \mathbf{0 . 0 2 7 6} & \\
\text { Interaction Tires Prosure with Tillage Sneeds } \cdot 00203 & \end{array}$} \\
\hline
\end{tabular}

\section{Conclusion}

The highest vibration levels on tractor steering wheel, tractor platform on three axes (longitudinal $\mathrm{X}$, lateral $\mathrm{Y}$ and vertical $\mathrm{Z}$ ), vertical vibration in seat tractor and Seat Effective Amplitude Transmissibility (SEAT) Factor were observed when used disc plow for tillage at higher inflation pressure 2.7 bar and highest operating tillage speed $6.50 \mathrm{~km} / \mathrm{hr}$ for the evaluated operations. Tire pressure $1.1 \mathrm{bar}$ and tillage speed $2.35 \mathrm{~km} / \mathrm{hr}$ observed least levels vibration on axes X,Y and Z, and SEAT Factor . No significant observed between chisel and disc plows in SEAT Factor. Increasing tillage speed result to higher vibration levels. Increasing inflation pressure result to stiffness tire and that led to higher vibration levels and decreasing damping. The results in these experiment when compared with international standards, values are found to be higher even for a $4 \mathrm{~h}$ exposure limit. Thus, it may be recommended that the field operations may not be continued beyond 3 hours per day and must tractor driver be rest at least 25 min after 3 hours tillage operation.

\section{REFRENCES}

1. Hamid, Ahmed. A. A. 2012 . Back Injury Vibration, Blood Pressure and Heart Rate in Operator Tractor. The second conference scientific for Machines and equipment agriculture. Iraqi Society of Soil Science journal ,12 (1) 199- 209.

2. Cutini, M., C Bisaglia and E Romano. 2007. Assessment of tractor's tires influence on operator's comfort. Proceedings of XXXII CIOSTAC onference.Nitra,Slovakia, Septemper. 3. Servadio, P., A Marsili and N.P Belfiore. 2007. Analysis of driving seat vibrations in high forward speed tractors Biosystems Engineering, 97, $171-180$.

4. Deboli, R., A. Calvo, C. Preti and G. Paletto, 2008. Whole Body Vibration (WBV) transmitted to the operator by tractors equipped with radial tires. International Conference "Innovation Technology to Empower Safety, Health and Welfare in Agriculture and Agro-food Systems",Italy

5. Quadros ,J. D, Suhas, V and B Shilpa. 2013. Study of vibration and its effects on health of a two wheeler rider. International Journal of Research in Engineering and Technology Volume: 02 Issue: 08 P $51-55$.

6. Zakaullah, Z M, A. Khaliq and M. Afzal 2014. Effect of Hand Transmitted Vibration through Tractor during Ploughing Field. Int. Journal of Engineering Research and 
Applications. Vol. 4, Issue 12(Part 6), December 2014, pp.18-23.

7.Hamid, A.A.A, K.A. Mudafer, A.H.A Ahmed and F.F Ali. 2011. Effect of Steering Wheel Vibration on drivers Hands in a Two-Wheel Drivers Hand tractor.Jurnal of Engineering. N6.V17.P 1539-1549. Iraq .

8. Dewangan, K.N., and V.K Tewari. 2008. Characteristics of vibration transmission in the hand arm system and subjective response during field operation of a hand tractor. Biosystem Engineering. volume 100, issue 4, pp 535-546.

9. Scarlett, A. J, J. S Price and R. M. Stayner. 2007.Whole-body vibration: evaluation of emission and exposure levels arising from agricultural tractors. Journal of Terramechanics, v. 44, n. 1, p. 65-73.

10. Zehsaz, M, M. H. Sadeghi, M. M Ettefagh and F. Shams. 2011. Tractors cabin's passive suspension parameters optimization via experimental and numeral methods. Journal of Terramechanics, v. 48, n. 6, p. 439-450.

11. Cvetanovic, B. and D. ZlatkovicL, 2013. Evaluation of whole-body vibration risk in agricultural tractor drivers. Bulg. J. Agric. Sci., 19: 1155-1160.

12. Villibor, Paula, F. Santos, D. Queiroz and D Guedes.2014. Vibration levels on rear and front axles of a tractor in agricultural operations. Acta Scientiarum Technology. v. 36, n. 1, p. 7-14.

13. ISO 2631-1-1997: Mechanical variation and Shock - Evaluation of Human Exposure to Whole Body Vibration. Part 1: General Requirements.

14. Petrović, P., Z. Bracanović and S. Vukas, 2005. Oscillatory appearance on agricultural of tractors.Agricultural Engineering,30 (2): 15 - 23. 15. Sakthivel, A, S. Sriraman, and R. Verma, Study of Vibration from Steering Wheel of an Agricultural Tractor, SAE Int. J. Commer. Veh.5(2):441-454, 2012.

16. Adolfson, N., 2012. Whole body vibrations indicators in agricultural tractors. NES 2012, Proceedings, Sweden.

17. Scarlett, A. J, J. S. Price, D. A. Semple and R. M. Stayner, 2005. Whole-body vibration on agricultural vehicles: evaluation of emission and estimated exposure levels. Research Report, UK. 18. Nguyen, V. N and S. Inaba .2011 . Effects of tire inflation pressure and tractor velocity on dynamic wheel load and rear axle vibrations. Journal of Terramechanics, v. 48, n. 1, p. 3-16. 19. Hansson, P.2002.Working Space requirment for an Agricultural Tractor Axle Suspension. Biosystems Engineering . 81(1), 57-71.

20. Kising, A and H. GoKhlich (1989). Dynamic characteristics of large tires. Journal of Agricultural Engineering Research, 43,11-21 . 21.Statistical Analysis System SAS .2010.User`s Guide. Statistics ( version 6.0). SAS Institute. Inc. Cary .NC.USA.

22. Al-Sahookie, M and M.W Kareema..1990.

Aplications in Design and analyses the experiments. Unevirsity of Baghdad. Ministry of Higher Education and Scientific Research . Hakma home for publish. Mousel UN.(In Arabic). pp 488.

23. ISO 5008:2002 Agricultural wheeled tractors and field machinery - measurement of whole body vibration of the operator . pp 482-492.

24. ISO 5349-1, 2001. Mechanical Vibration Measurement and Evaluation of Human Exposure to Hand-Transmitted Vibration - Part 1: General Requirements .

25. Gogliaa, V, Z. Gospod, S. Kosutic and D. Filipo.2003. Hand-transmitted vibration from the steering wheel to drivers of a small four wheel drive tractor. Applied Ergonomic 34. 45- 49.

26. ISO 5349:1989. Mechanical vibration Guidelines for the measurement and the assessment of human exposure to handtransmitted vibration. Geneva.

27. Santia. 2014 Vibration Guidance Note 31 . available in internet: www.santia.co.uk/accreditation. pp 1-14.

28.ISO 10326-1 (1992). Mechanical vibration laboratory method for evaluating vehicle seat vibration: Part 1: Basic requirements. Geneva.

29.ISO 5007:2003. Agricultural wheeled tractors Operator's seat laboratory measurement of transmitted vibration. Geneva. pp 475-481.

30. American Society of Agricultural and Biological Engineers (ASABE) .2007. ASABE/ISO 5007:2003 Adopted by ASABE May 2006. Agricultural wheeled tractors Operator's seat measurement of transmitted vibration. ASABE, 2950 Niles Road, St. Joseph, MI 49085-9659, USA, hq@ asabe.org.

31. Yoo, W.S., S.D. Na and M.S. Kim, 2011. Relationship between Subjective and Objective 
Evaluations of Steering Wheel Vibration. Journal of Mechanical Science and Technology, 25(7): $1695-1701$.

32. ISO 5349-2, 2001. Mechanical Vibration Measurement and Evaluation of Human Exposure to Hand-Transmitted Vibration - Part 2: Practical Guidance for Measurement at the Workplace.

33.Tewari,V.K, K.P Vidhu, A. Arudra and S. Kumari.2013. Reduction of hand transmitted and whole body vibrations experienced by tractor operators by using piezo crystal material. Agric Eng Int: CIGR Journal.Vol. 15, No.2 209 p 209
- 220.Open access at http://www.cigrjournal.org. 34. Dom, C, Z Sihong and Z Yue: Effects of Tire Inflation Pressure and Forward Speed on vibration of an Unsuspended Tractor. Journal of Terra mechanics, 2013, nr 50, s. 185-198.

35. Kristina, K, Z. Vidas and W. Dariusz. Shock absorber efficiency measurement impact of tires types and pressure. The archives of automotive engineering. Warszawa : Wydawnic two Naukowe PWN. ISSN 1234-754X. Vol. 64, no. 2 p. 27-36, 127-136. 